\title{
TRACER STUDY MENGGUNAKAN FRAMEWORK BOOTSTRAP
}

\author{
Ramadiani ${ }^{1}$, Putut Pamilih Widagdo *,2, Eko Junirianto ${ }^{3}$ \\ 1,2,3 Program Studi Ilmu Komputer, Fakultas Ilmu Komputer dan Teknologi Informasi, Universitas Mulawarman \\ Jalan Barong Tongkok Kampus Gunung Kelua Samarinda, Kalimantan Timur \\ Email : mmi_ugm04@yahoo.com¹, pututpamilih@gmail.com², eko.ilkom@gmail.com³
}

\begin{abstract}
ABSTRAK
Tracer study merupakan salah satu sistem informasi yang telah banyak dipergunakan oleh perguruan tinggi di dunia untuk melakukan pengumpulan data lulusan. Sistem informasi tracer study telah mulai diterapkan di Indonesia khususnya pada Universitas Mulawarman Samarinda untuk melakukan pendataan alumni, di mana data tersebut dipergunakan untuk memenuhi kebutuhan akreditasi perguruan tinggi dan melakukan perencanaan strategis dalam meningkatkan mutu kualitas lulusan Universitas Mulawarman. Penelitian ini bertujuan untuk melakukan analisis perancangan kebutuhan sistem tracer study Universitas Mulawarman yang disesuaikan dengan kebutuhan informasi dalam proses akreditasi baik ditingkat program studi, fakultas, universitas, dan Dikti. Berdasarkan hasil penelitian ini didapatkan hasil perancangan sistem informasi tracer study di perguruan tinggi memiliki banyak manfaat diantaranya : 1. Memenuhi kebutuhan data dan informasi terkait lulusan, 2. Memenuhi kebutuhan data akreditasi perguruan tinggi, 3. Mempermudah perguruan tinggi dalam mengelola data lulusan, dan 4. Memudahkan perguruan tinggi dalam menunjang keputusan menentukan perencanaan strategis sebagai upaya peningkatan kualitas mutu lulusan. Diharapkan dengan diterapkannya sistem tracer study pada perguruan tinggi di Indonesia akan meningkatkan kualitas lulusan yang memiliki daya serap tinggi terhadap kebutuhan pasar kerja saat ini maupun dimasa mendatang.
\end{abstract}

Kata kunci : Sistem Informasi, Tracer Study, lulusan, Kuesioner, Frameworks Boostrap.

\section{PENDAHULUAN}

Perkembangan Teknologi informasi yang semakin pesat mendorong banyak organisasi dan perusahaan berupaya untuk dapat menunjukkan keunggulan kompetitif agar dapat terus bertahan. Teknologi Informasi merupakan salah satu kekuatan fundamental organisasi/perusahaan dalam memberikan keuntungan tangible (berwujud) dan intangible (tidak berwujud). Kemajuan teknologi juga merupakan bukti keunggulan kompetitif sebuah organisasi untuk dapat terus maju dan berkembang dalam meningkatkan kualitas layanan kepada seluruh pemangku kepentingan di lingkungan organisasi.

Saat ini banyak perguruan tinggi berupaya untuk menggali informasi mengenai lulusan atau alumni yang berkaitan dengan transisi dari kegiatan perkuliahan ke pekerjaan yaitu dengan melaksanakan sebuah studi yang disebut tracer study [6]. Kebutuhan akan data dan informasi mengenai lulusan/ alumni bagi perguruan tinggi sangatlah penting, selain sebagai upaya peningkatan nilai akreditasi perguruan tinggi dapat juga digunakan untuk mengetahui informasi mengenai serapan pekerjaan, perkembangan alumni, masa tunggu alumni, jenis pekerjaan, kesulitan-kesulitan alumni di dunia pekerjaan dan masih banyak lagi. Tracer study dilaksanakan dengan cara melakukan survey terhadap lulusan atau alumni yang memungkinkan adanya evaluasi dari hasil kegiatan pendidikan yang dilaksanakan oleh perguruan tinggi dengan kebutuhan pekerjaan saat ini dan perencanaan strategis dalam meningkatkan kualitas lulusannya di masa mendatang.

Universitas Mulawarman Samarinda merupakan Perguruan Tinggi Negeri (PTN) yang ada di provinsi Kalimantan Timur yang memiliki database terkait dengan keberadaan mereka setelah lulusan. Hal ini menyebabkan kesulitan bagi Universitas Mulawarman dalam mengetahui keberadaan lulusannya, mereka bekerja dimana, apa kesulitan-kesulitan mereka hadapi, apakah keterkaitan ilmu semasa kuliah relevan dengan kebutuhan dunia kerja, dan kebutuhan informasi terkait umpan balik lulusan yang dipergunakan untuk perbaikan kurikulum dan kebutuhan akreditasi program studi dan perguruan tinggi.

Hal-hal tersebut diatas yang mendasari Universitas Mulawarman Samarinda untuk membangun sebuah sistem informasi Tracer Study. Sistem informasi Tracer study yang dikembangkan oleh Universitas Mulawarman merupakan aplikasi untuk mengumpulkan data terkini (update) berkaitan dengan lulusan, dimana data-data tersebut akan diolah untuk dijadikan informasi yang dapat dipergunakan dalam menunjang keputusan arah perencanaan jangka pendek dan jangka panjang yang diputuskan dalam bentuk perencanaan strategis meningkatkan serapan alumni dalam memperoleh pekerjaan serta mengatasi kesulitankesulitan yang selama ini sering dihadapi oleh 
alumni/lulusan Universitas Mulawarman dalam memperoleh pekerjaan. Sistem informasi tracer study yang dikembangkan mudah dipergunakan dalam mengumpulkan data dan informasi lulusan/alumni yang tersebar di seluruh Indonesia karena kemudahan aksesnya yang selalu tersedia kapan saja dan dimana saja (online).

Dalam upaya meningkatkan kualitas mutu sumber daya manusia lulusan perguruan tinggi di Indonesia, maka keberadaan sistem informasi tracer study ini tentu sangat penting, karena akan memberikan kemudahan perguruan tinggi dalam merumuskan kebijakan dan sasaran-sasaran strategis untuk memperbaiki kualitas dan kompetensi lulusan saat ini dan di masa mendatang. Secara khusus harapan kedepannya lulusan Universitas Mulawarman diharapkan saat terjun ke dunia pekerjaan akan mampu bersaing dan mudah dalam memperoleh pekerjaan yang sesuai dengan kebutuhan tenaga kerja di Indonesia.

\section{TINJAUAN PUSTAKA}

\section{a. Tracer Study}

Tracer study adalah rekam jejak alumni/lulusan setelah selesai melakukan proses pendidikan di perguruan tinggi, secara umum mengeksplorasi perspektif unik dari lulusan pendidikan tinggi mengenai kontribusi dunia pendidikan terhadap kehidupan mereka setelah lulus [9]. Tracer study adalah survey lulusan atau alumni yang mencoba untuk melacak kegiatan lulusan institusi pendidikan, Tracer study memungkinkan untuk menghubungkan lulusan dari suatu perguruan tinggi tertentu menggunakan sistem yang dinamis dan dapat diandalkan untuk menjelaskan riwayat kehidupan atau kegiatan dalam upaya mendapatkan pejerjaan [6].

Dengan sistem informasi tracer study ini dapat dipergunakan untuk melacak alumni, melakukan evaluasi dari hasil pendidikan oleh perguruan tinggi, mengetahui kondisi alumni, bagaimana mereka bekerja, kompetensi yang dimiliki. Mengetahui karir lulusan saat ini dan prospek kerja lulusan dengan kebutuhan pasar kerja saat ini dan masa mendatang. Berdasarkan informasi tracer study dapat dipergunakan oleh perguruan tinggi untuk meningkatkan kualitas dan mutu lulusannya dengan pengambilan kebijakan-kebijakan strategis dan perbaikan proses pendidikan.

\section{b. Frameworks Boostrap}

Frameworks Bootstrap adalah front-end framework yang mengedapankan tampilan untuk mobile device (Handphone, smartphone dll.) untuk mempercepat dan mempermudah pengembangan website. Bootstrap menyediakan HTML, CSS dan Javascript siap dipergunakan dan mudah untuk dikembangkan. Bootstrap merupakan framework untuk membangun desain web secara responsif. Responsif artinya tampilan web yang dibuat menggunakan bootstrap akan secara otomatis menyesuaikan ukuran layar dari browser yang dipergunakan baik di komputer, tablet, ataupun mobile device. Dalam membuat web untuk tampilan dapat disesuaikan dengan kebutuhan apabila dipergunakan oleh mobile browser maka tampilan dari web yang dibuat akan dapat berfungsi menyesuiakan dengan lebar layar dari perangkat tersebut. Dengan menggunakan bootstrap memepermudah dalam membangun web dinamis ataupun statis [4].

\section{HASIL DAN PEMBAHASAN}

Dalam perancangan dan pembangunan sistem tracer study ini terdapat tahapan-tahapan penelitian yang dilakukan meliputi :

1. Tahap Pengumpulan Data

Melakukan pengumpulan data yang berhubungan dengan kebutuhan tracer study di Universitas Mulawarman, Dikti, database MySQL, Desain antar muka dan desain sistem, Framework boostrap, Pengumpulan data diperoleh melalui wawancara dengan bagian kemahasiswaan rektorat dan LP3M sebagai penjaminan mutu Unmul, studi literatur lewat buku-buku maupun artikel serta jurnal ilmiah.

2. Tahap Perencanaan Memahami permasalahan, mengidentifikasi, dan mendefinisikan secara rinci setiap masalah berserta kendalanya dan menyusun langkahlangkah penyelesaiannya.

3. Tahap Analisis

Masalah dan langkah penyelesaian yang telah disusun dilakukan analisis untuk mendapatkan solusi yang tepat untuk menerapkannya kedalam sistem.

4. Tahap Perancangan

Menentukan kebutuhan sistem, hak akses pengguna, merancang dalam bentuk use case, membuat struktur basis data dan interface yang disesuaikan agar mudah untuk dipergunakan

5. Tahap Penerapan

Pemrograman menggunakan bahasa PHP dan framework boostrap yang telah dipilih kemudian diimplementasikan untuk menjadi sebuah aplikasi perangkat lunak berbasis web.

6. Tahap Evaluasi (Pengujian)

Pengujian sistem dilakukan pengguna dengan mengakses sistem informasi tracer study unmul sesuai dengan proses bisnis yang sesuai aksesnya.

7. Tahap Pemeliharaan

Memperbaiki kesalahan dan kemampuan kinerja sistem jika mengalami gangguan dan adanya penyesuaian kebutuhan pengembangan sistem. 


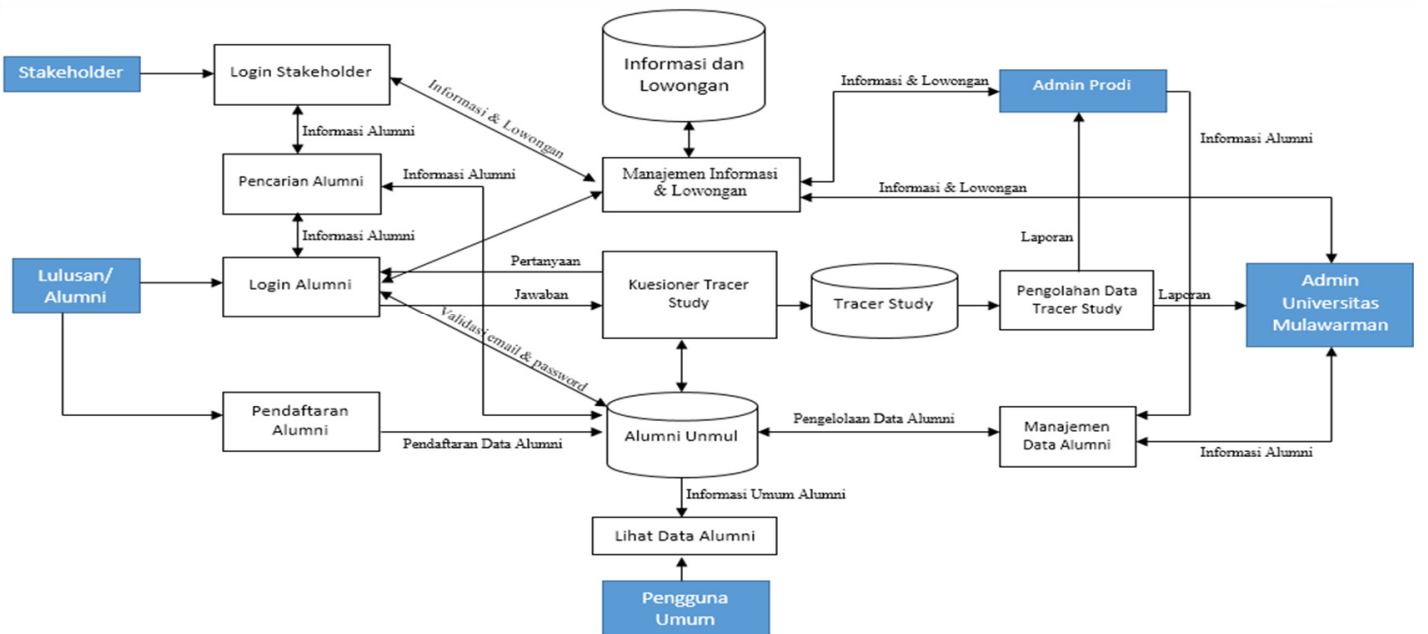

Gambar 1. Rancangan Penelitian

Dalam sebuah sistem informasi tentunya dibutuhkan sebuah perancangan Pada gambar 1 merupakan penjelasan rancangan penelitian dimana terdapat 5 pengguna sistem informasi tracer study Universitas Mulawarman yaitu pengguna umum, alumni unmul, admin unmul, admin program studi, dan stakeholder. Setiap pengguna memiliki hak akses yang telah disesuaikan dengan kebutuhan sistem sehingga tidak terjadi penyalahgunaan akses. Kuesioner tracer study menggunakan acuan berdasarkan pada point-point yang dibutuhkan dalam penyusunan data akreditasi baik ditingkat program studi, fakultas, dan perguruan tinggi. Hasil kuesioner tersebut kemudian dilakukan analisis dan diolah untuk kemudian menjadi laporan-laporan informasi yang berkaitan dengan lulusan.

Pengembangan dan perancangan sistem informasi tracer study yang dilakukan dengan menggunakan UML, semua aktivitas dari pengguna dimodelkan berdasarkan pada fungsinya secara spesifik. Use case dipergunakan untuk menjelaskan interaksi pengguna dengan sistem tracer study yang disesuaikan dengan hak akses dan fungsinya dalam sistem. Berdasarkan gambaran use case berikut ini dapat terlihat proses bisnis yang diharapkan dari sistem informasi yang akan dikembangkan.

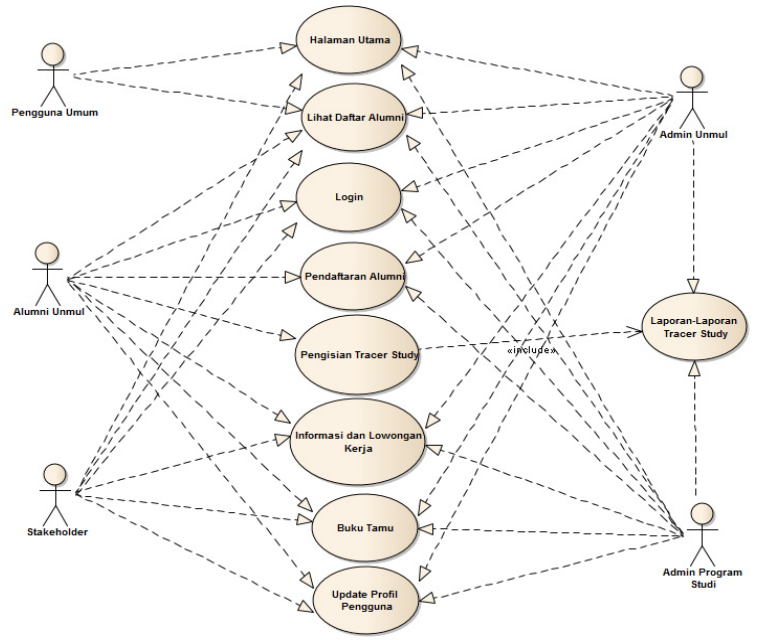

Gambar 2. Use Case Diagram Tracer Study
Berdasarkan pada gambar 2 terlihat bahwa setiap pengguna telah memiliki hak akses dan fungsinya masing-masing dalam sistem informas tracer study dimana sumber datanya adalah lulusan/ alumni yang diharuskan untuk mengisi kuesioner tracer study yang tersedia di dalam sistem informasi (login). Sedangkan admin unmul dan admin program studi berfungsi sebagai pengelola data tracer study yang diolah menjadi laporan tracer study yang akan dipergunakan sebagai informasi dalam meningkatkan nilai akreditasi dan penunjang keputusan bagi pimpinan di Universitas Mulawarman. Tabel berikut ini akan menjelaskan use case diagram tracer study :

Tabel 1. Penjelasan Use Case Diagram Tracer Study

\begin{tabular}{|l|l|l|}
\hline Aktor & Nama Use Case & Penjelasan \\
\hline Umum & Halaman Utama & $\begin{array}{l}\text { Berfungsi untuk } \\
\text { melihat halaman } \\
\text { utama website }\end{array}$ \\
\hline Umum & $\begin{array}{l}\text { Lihat daftar } \\
\text { alumni }\end{array}$ & $\begin{array}{l}\text { Berfungsi untuk } \\
\text { dapat melihat } \\
\text { daftar alumni yang } \\
\text { telah terdaftar }\end{array}$ \\
\hline Alumni & Halaman Utama & $\begin{array}{l}\text { Berfungsi untuk } \\
\text { melihat halaman } \\
\text { utama website }\end{array}$ \\
\hline Alumni & $\begin{array}{l}\text { Lihat daftar } \\
\text { alumni }\end{array}$ & $\begin{array}{l}\text { Berfungsi melihat } \\
\text { daftar alumni yang } \\
\text { telah terdaftar }\end{array}$ \\
\hline Alumni & Login & $\begin{array}{l}\text { Berfungsi login } \\
\text { sebagai alumni }\end{array}$ \\
\hline Alumni & Pendaftaran & $\begin{array}{l}\text { Berfungsi } \\
\text { melakukan } \\
\text { pendaftaran } \\
\text { sebagai alumni }\end{array}$ \\
\hline Alumni & $\begin{array}{l}\text { Pengisian } \\
\text { Tracer Study } \\
\text { melakukan } \\
\text { pengisian } \\
\text { kuesioner tracer } \\
\text { study } \\
\text { merupakan }\end{array}$ \\
\hline
\end{tabular}




\begin{tabular}{|c|c|c|}
\hline & & $\begin{array}{l}\text { fasilitas } \\
\text { pengumpulan data } \\
\text { utama dalam } \\
\text { aplikasi ini. }\end{array}$ \\
\hline Alumni & $\begin{array}{l}\text { Informasi dan } \\
\text { lowongan kerja }\end{array}$ & $\begin{array}{l}\text { Berfungsi untuk } \\
\text { mengelola } \\
\text { informasi dan } \\
\text { lowongan kerja }\end{array}$ \\
\hline Alumni & Buku Tamu & $\begin{array}{l}\text { Berfungsi sebagai } \\
\text { fasilitas atau media } \\
\text { komunikasi } \\
\text { pengguna. }\end{array}$ \\
\hline Alumni & $\begin{array}{l}\text { Update profil } \\
\text { alumni }\end{array}$ & $\begin{array}{l}\text { Berfungsi untuk } \\
\text { melakukan } \\
\text { perbaikan data } \\
\text { profil alumni } \\
\text { mulai dari biodata, } \\
\text { foto, hingga } \\
\text { password login. }\end{array}$ \\
\hline $\begin{array}{l}\text { Stakeh } \\
\text { older }\end{array}$ & n utama & $\begin{array}{lr}\text { Berfungsi } & \text { melihat } \\
\text { halaman } & \text { utama } \\
\text { website } & \\
\end{array}$ \\
\hline $\begin{array}{l}\text { Stakeh } \\
\text { older }\end{array}$ & $\begin{array}{l}\text { Lihat daftar } \\
\text { alumni }\end{array}$ & $\begin{array}{l}\text { Berfungsi melihat } \\
\text { data alumni yang } \\
\text { terdaftar }\end{array}$ \\
\hline $\begin{array}{l}\text { Stakeh } \\
\text { older }\end{array}$ & Login & $\begin{array}{lr}\text { Berfungsi } & \text { untuk } \\
\text { login } & \text { sebagai } \\
\text { stakeholder } & \\
\end{array}$ \\
\hline $\begin{array}{l}\text { Stakeh } \\
\text { older }\end{array}$ & $\begin{array}{l}\text { Informasi dan } \\
\text { lowongan kerja }\end{array}$ & $\begin{array}{l}\text { Berfungsi untuk } \\
\text { mengelola } \\
\text { informasi dan } \\
\text { lowongan kerja. }\end{array}$ \\
\hline $\begin{array}{l}\text { Stakeh } \\
\text { older }\end{array}$ & Buk & $\begin{array}{l}\text { Berfungsi sebagai } \\
\text { fasilitas atau media } \\
\text { komunikasi antar } \\
\text { pengguna }\end{array}$ \\
\hline $\begin{array}{l}\text { Stakeh } \\
\text { older }\end{array}$ & Update profil & $\begin{array}{l}\text { Berfungsi untuk } \\
\text { melakukan } \\
\text { perbaikan data } \\
\text { profil alumni } \\
\text { mulai dari biodata, } \\
\text { foto, hingga } \\
\text { password login. }\end{array}$ \\
\hline $\begin{array}{l}\text { Admin } \\
\text { Unmul }\end{array}$ & n Utama & $\begin{array}{l}\text { Berfungsi untuk } \\
\text { melihat halaman } \\
\text { utama website }\end{array}$ \\
\hline $\begin{array}{l}\text { Admin } \\
\text { Unmul }\end{array}$ & $\begin{array}{l}\text { Lihat daftar } \\
\text { alumni }\end{array}$ & $\begin{array}{l}\text { Berfungsi melihat } \\
\text { daftar alumni yang } \\
\text { telah terdaftar }\end{array}$ \\
\hline $\begin{array}{l}\text { Admin } \\
\text { Unmul }\end{array}$ & Login & $\begin{array}{lr}\text { Berfungsi } & \text { untuk } \\
\text { login } & \text { sebagai } \\
\text { admin unmul }\end{array}$ \\
\hline $\begin{array}{l}\text { Admin } \\
\text { Unmul }\end{array}$ & $\begin{array}{l}\text { Pendaftaran } \\
\text { Alumni }\end{array}$ & $\begin{array}{l}\text { Berfungsi } \\
\text { mendaftarkan } \\
\text { alumni }\end{array}$ \\
\hline $\begin{array}{l}\text { Admin } \\
\text { Unmul }\end{array}$ & $\begin{array}{l}\text { Informasi dan } \\
\text { lowongan kerja }\end{array}$ & $\begin{array}{l}\text { Berfungsi untuk } \\
\text { mengelola } \\
\text { informasi dan } \\
\text { lowongan kerja }\end{array}$ \\
\hline $\begin{array}{l}\text { Admin } \\
\text { Unmul }\end{array}$ & Buku Tamu & $\begin{array}{l}\text { Berfungsi sebagai } \\
\text { fasilitas atau media }\end{array}$ \\
\hline
\end{tabular}

\begin{tabular}{|c|c|c|}
\hline & & $\begin{array}{l}\text { komunikasi antar } \\
\text { pengguna }\end{array}$ \\
\hline $\begin{array}{l}\text { Admin } \\
\text { Unmul }\end{array}$ & $\begin{array}{l}\text { Update profil } \\
\text { alumni }\end{array}$ & $\begin{array}{l}\text { Berfungsi untuk } \\
\text { melakukan } \\
\text { perbaikan data } \\
\text { profil alumni } \\
\text { mulai dari biodata, } \\
\text { foto, hingga } \\
\text { password login. }\end{array}$ \\
\hline $\begin{array}{l}\text { Admin } \\
\text { Unmul }\end{array}$ & $\begin{array}{l}\text { Laporan- } \\
\text { Laporan Tracer } \\
\text { Study }\end{array}$ & $\begin{array}{lr}\text { Berfungsi sebagai } \\
\text { hasil dari proses } \\
\text { pengolahan data } \\
\text { pengisian tracer } \\
\text { studi yang di isi } \\
\text { oleh alumni. }\end{array}$ \\
\hline $\begin{array}{l}\text { Admin } \\
\text { Progra } \\
\text { m studi } \\
\end{array}$ & Halaman Utama & $\begin{array}{l}\text { Berfungsi untuk } \\
\text { melihat halaman } \\
\text { utama web }\end{array}$ \\
\hline $\begin{array}{l}\text { Admin } \\
\text { Progra } \\
\text { m studi }\end{array}$ & $\begin{array}{ll}\text { Lihat daftar } \\
\text { alumni }\end{array}$ & $\begin{array}{l}\text { Berfungsi melihat } \\
\text { daftar lulusan } \\
\text { berdasarkan } \\
\text { program studi. }\end{array}$ \\
\hline $\begin{array}{l}\text { Admin } \\
\text { Progra } \\
\text { m studi }\end{array}$ & Login & $\begin{array}{lr}\text { Berfungsi } & \text { untuk } \\
\text { login } & \text { sebagai } \\
\text { admin } & \text { program } \\
\text { studi } & \\
\end{array}$ \\
\hline $\begin{array}{l}\text { Admin } \\
\text { Progra } \\
\text { m studi }\end{array}$ & $\begin{array}{l}\text { Pendaftaran } \\
\text { Alumni }\end{array}$ & $\begin{array}{l}\text { Berfungsi untuk } \\
\text { mendaftarkan } \\
\text { alumni } \\
\text { berdasarkan prodi }\end{array}$ \\
\hline $\begin{array}{l}\text { Admin } \\
\text { Progra } \\
\text { m studi }\end{array}$ & $\begin{array}{l}\text { Informasi dan } \\
\text { lowongan kerja }\end{array}$ & $\begin{array}{l}\text { Berfungsi } \\
\text { mengelola } \\
\text { informasi dan } \\
\text { lowongan kerja. }\end{array}$ \\
\hline $\begin{array}{l}\text { Admin } \\
\text { Progra } \\
\text { m studi }\end{array}$ & Buku Tamu & $\begin{array}{l}\text { Berfungsi sebagai } \\
\text { media fasilitas dan } \\
\text { media komunikasi } \\
\text { antar pengguna }\end{array}$ \\
\hline $\begin{array}{l}\text { Admin } \\
\text { Progra } \\
\text { m studi }\end{array}$ & $\begin{array}{l}\text { Update profil } \\
\text { alumni }\end{array}$ & $\begin{array}{l}\text { Berfungsi untuk } \\
\text { melakukan } \\
\text { perbaikan data } \\
\text { profil admin prodi } \\
\text { mulai dari biodata, } \\
\text { foto, password, }\end{array}$ \\
\hline $\begin{array}{l}\text { Admin } \\
\text { Progra } \\
\text { m studi }\end{array}$ & $\begin{array}{l}\text { Laporan- } \\
\text { Laporan Tracer } \\
\text { Study }\end{array}$ & $\begin{array}{lr}\text { Berfungsi } & \text { untuk } \\
\text { mengelola } & \\
\text { informasi menjadi } \\
\text { laporan tracer } \\
\text { study berdasarkan } \\
\text { prodi }\end{array}$ \\
\hline
\end{tabular}

\section{A. Klasifikasi Pengguna}

Berdasarkan analisis kebutuhan sistem informasi tracer study Universitas Mulawarman terdapat 5 pengguna yaitu :

\section{Admin Unmul}

Admin Universitas Mulawarman memiliki hak dan wewenang khusus untuk mengelola/manajemen data keseluruhan sistem informasi tracer study Universitas Mulawarman. Admin Unmul bertugas 
untuk mengelola data dan memiliki tanggung jawab penuh terhadap data dan informasi dari tracer study. Admin unmul memiliki semua akses dan layanan aplikasi sehingga informasi yang disajikan lebih akurat, efektif, dan efisien dalam membantu pimpinan dalam mengambil keputusan.

\section{Admin Program Studi Unmul}

Pada admin program studi memiliki hak akses dan mengelola data dan informasi hanya berdasarkan pada asal program studi, Artinya admin program studi tidak dapat melihat data tracer study dari progam studi lain karena adanya pembatasan akses. Admin program studi bertugas untuk melakukan validasi dan mencek data alumni apakah telah sesuai dengan data di program studi. Data tracer study nantinya dapat digunakan oleh program studi untuk digunakan dalam proses akreditasi program studi.

\section{Lulusan/Alumni Unmul}

Alumni Unmul merupakan sumber data dari tracer study dimana alumni wajib melakukan pendaftaran untuk dapat masuk ke dalam aplikasi sistem informasi tracer study untuk kemudian mengisi kuesioner tracer study. Alumni mendapatkan kemudahan untuk registrasi dengan menggunakan email untuk melakukan pendaftaran setelah itu dapat login dan mengisi tracer study.

\section{Stakeholder}

Stakeholder adalah pihak ketiga yang bekerjasama dengan Universitas Mulawarman bisa berupa perseorangan, badan, instansi, unit usaha, atau perusahaan. Stakeholder dalam tracer study berperan sebagai bagian dari pengguna lulusan/alumni Unmul yang juga memberikan masukan (feedback) dari pemanfaatan lulusan. Stakeholder dapat memberikan informasi berupa informasi dan lowongan pekerjaan di dalam sistem informasi tracer study yang akan bermanfaat bagi alumni untuk memudahkan dalam mencari pekerjaan.

\section{Pengguna Umum}

Pengguna umum merupakan pengguna biasa yang hanya dapat melihat informasi umum dari sistem informasi tracer study seperti halaman berita dan melihat daftar alumni unmul yang telah terdaftar dalam sistem ini.

\section{HASIL DAN PEMBAHASAN}

\subsection{Deskripsi Sistem}

Aplikasi sistem informasi tracer study merupakan salah satu teknologi yang bermanfaat dalam membantu Universitas Mulawarman mengambil keputusan strategis yang berdampak terhadap peningkatan kualitas sumber daya manusia yang bermanfaat bagi seluruh stakeholder pengguna lulusan/alumni. Aplikasi sistem informasi tracer study Unmul dibangun menggunakan bahasa pemrograman PHP (PHP Hypertext Preprocessor) dengan MySQL sebagai databasenya. Dalam upaya penggumpulan data tracer study berupa kuesioner tentunya membutuhkan tampilan khusus, baik itu pertanyaan, jumlah pertanyaan, dan cara menjawabnya sehingga lulusan/alumni merasa mudah untuk memberikan informasinya. Sebab itulah pada sistem informasi tracer study ini menggunakan teknologi framework boostrap yang memiliki tampilan, desain, dan sifat mudah untuk digunakan (ease of use).

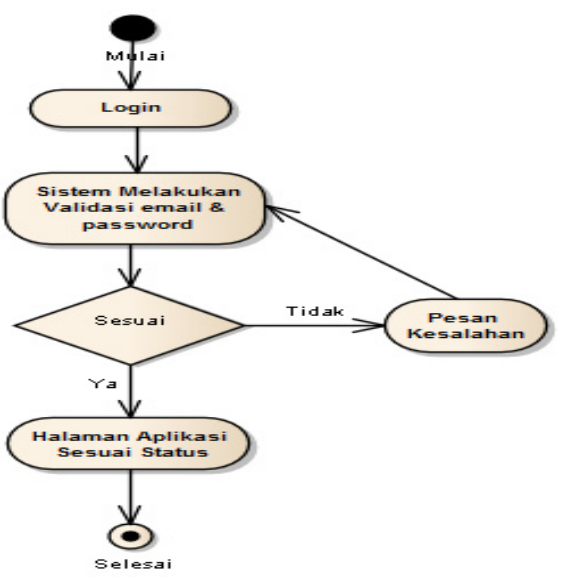

Gambar 3. Activity Diagram Login Pengguna

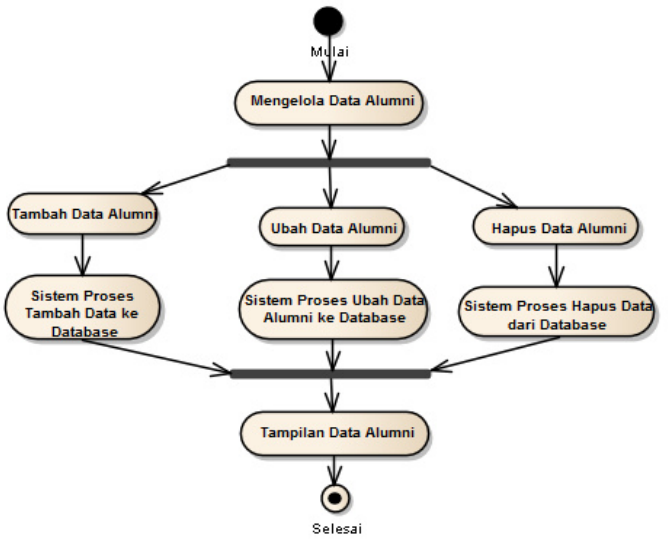

Gambar 4. Activity Diagram Manajemen Data Alumni

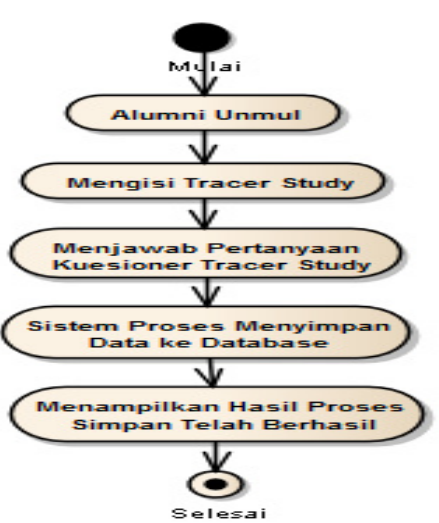

Gambar 5. Activity Diagram Pengisian Kuesioner Tracer Study 


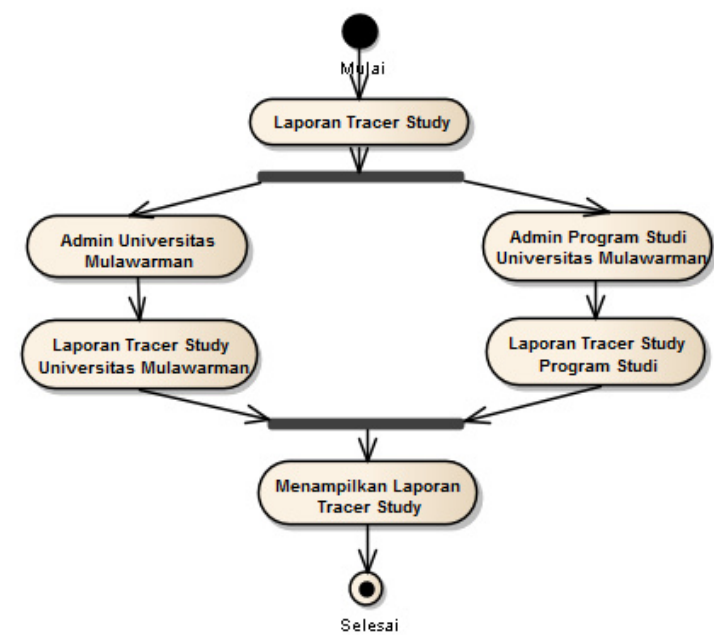

Gambar 6. Activity Diagram Laporan Tracer Study

\section{B. Desain Antar Muka}

Pada gambar menunjukkan halaman utama website tracer study Unmul, halaman ini adalah halaman yang bisa dikunjungi oleh seluruh pengguna. Informasi yang diberikan pada halaman ini adalah berita kegiatan lulusan, jumlah lulusan yang terdaftar (grafik), menu visi dan misi, pendaftaran alumni, lihat daftar alumni, kontak, dan login.

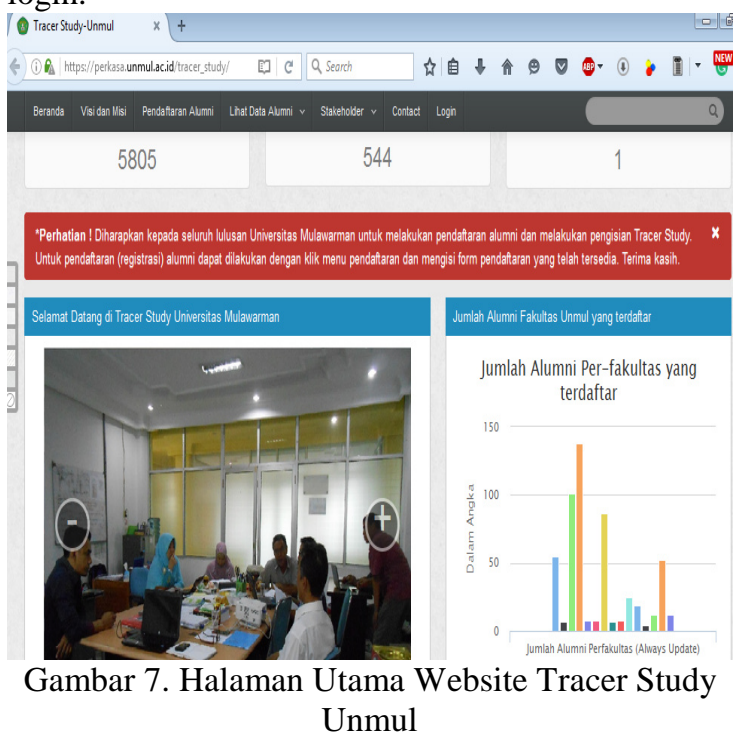

Pada gambar halaman form pendaftaran lulusan/alumni untuk alumni yang belum terdaftar dalam sistem informasi tracer study. Pada halaman ini alumni melakukan pendaftaran dengan mengisi biodata atau profil alumni. Untuk dapat masuk kedalam sistem pergunakan email dan password yang telah didaftarkan saat mengisi form ini.

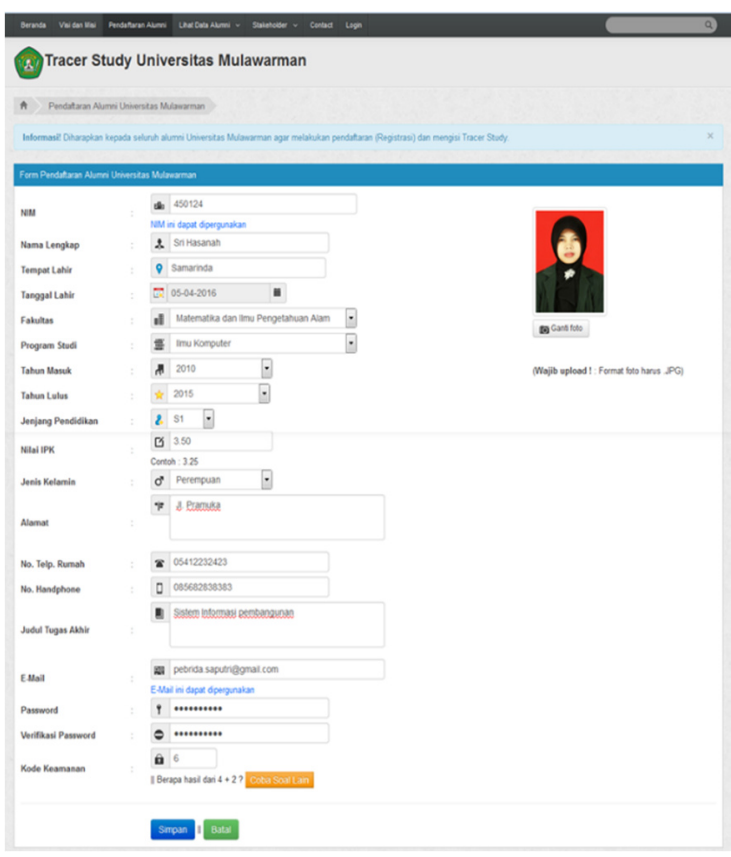

Gambar 8. Halaman Form Pendaftaran Alumni

Pada gambar halaman data alumni yang terdaftar dapat diketahui lulusan/alumni yang telah melakukan pendaftaran dalam sistem informasi tracer study Unmul. Pada halaman ini ditambahkan fasilitas pencarian dan cek lulusan/alumni sudah melakukan pengisian tracer study atau belum.

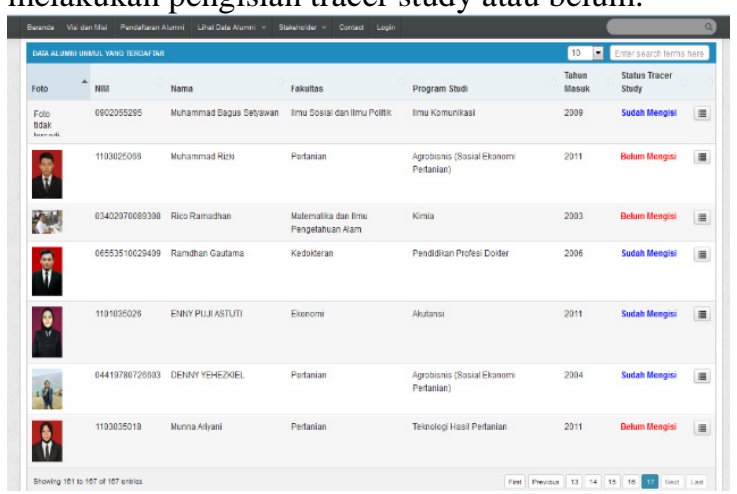

Gambar 9. Halaman Data Alumni Terdaftar

Pada gambar halaman kuesioner tracer study ini terdapat isian yang harus di isi oleh alumni untuk pengumpulan data tentang alumni yang terdiri dari 24 bagian. Pertanyaan kuesioner tracer study disesuaikan dengan kebutuhan perguruan tinggi terkait data akreditasi dan kebutuhan analisis perencanaan Universitas Mulawarman. Setiap bagian memiliki item-item pertanyaan sendiri seperti apakah sudah bekerja, tingkat kepuasan, tingkat keterkaitan ilmu, kesulitan-kesulitan dalam mendapat pekerjaan dan lain-lain. 


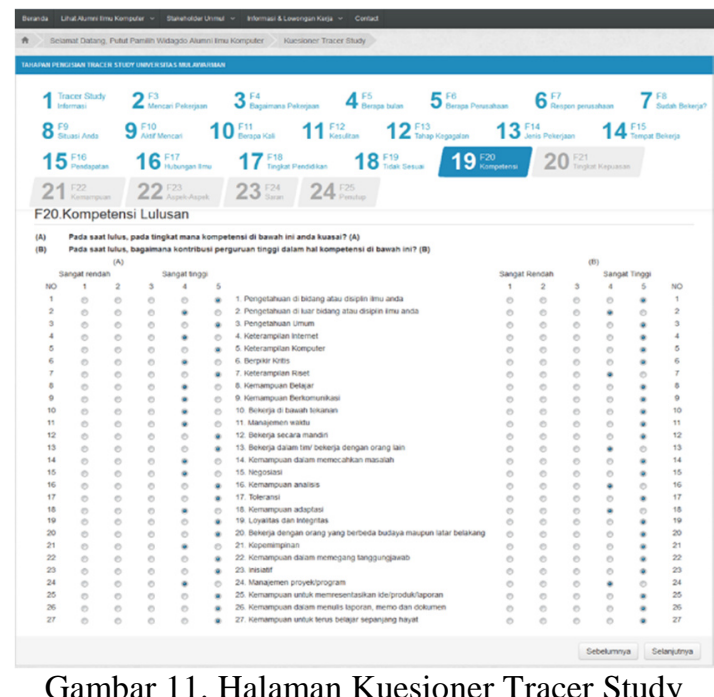

Gambar 11. Halaman Kuesioner Tracer Study

Pada gambar halaman laporan tracer study merupakan hasil pengolahan data dari isian kuesioner yang dilakukan oleh lulusan/alumni. Tampilan laporan berupa diagram chart, diagram batang, dan angka atau persentase. Laporan tracer study hanya dapat diakses oleh admin unmul dan admin program studi yang dipergunakan untuk kepentingan akreditasi dan pemutakhiran data lulusan/alumni.

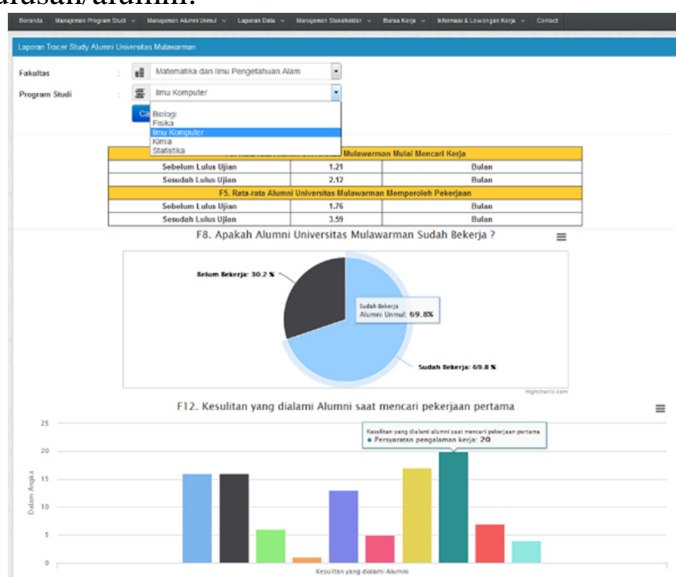

Gambar 12. Halaman Laporan Tracer Study

Pada gambar halaman laporan tracer study tingkat kepuasan merupakan salah satu bentuk laporan yang merupakan hasil pengolahan data isian kuesioner lulusan/alumni. Dari gambar ini dapat diketahui tingkat kepuasan lulusan/alumni terhadap perguruan tinggi, dan masih ada menu laporan lainnya seperti jenis pekerjaan, tingkat kesulitan, persentase pekerjaan dan lain-lain.

\section{KESIMPULAN}

Berdasarkan hasil penelitian dan pembahasan yang dilakukan maka dapat ditarik kesimpulan sebagai berikut :

1. Sistem ini dapat dipergunakan untuk mengelola data tracer study yang dapat diakses secara online berbasis web.

2. Sistem informasi ini sangat mudah dipergunakan oleh lulusan dalam melakukan pendaftaran dan pengisian tracer study karena menggunakan frameworks boostrap yang memiliki user interface yang baik.

3. Sistem informasi tracer study dapat dipergunakan Universitas Mulawarman dalam memenuhi kebutuhan data lulusan/alumni berkaitan dengan data akreditasi baik pada tingkat program studi, fakultas, dan Universitas.

4. Hasil pengolahan data berupa pelaporan informasi tracer study dapat memudahkan Universitas Mulawarman menganalisis kebutuhan dan pengambilan kebijakan dan perencanaan strategis dalam upaya meningkatkan kualitas mutu lulusan/alumni.

\section{SARAN}

Berdasarkan hasil penelitian ini maka saran bagi pengembangan penelitian ini yaitu :

1. Perlunya sosialisasi tracer study kepada para lulusan/alumni sehingga timbul kesadaran lebih untuk mengisi tracer study.

2. Mengingat pentingnya data dan informasi tracer study bagi perguruan tinggi maka perlu adanya pelatihan dan sosialisasi kepada para pengguna sistem tracer study.

3. Pada pengembangan selanjutnya, sistem informasi tracer study sebaiknya terintegrasi dengan sistem informasi akademik, sehingga saat mahasiswa telah menyelesaikan masa studinya dan telah lulus maka data langsung dapat digunakan untuk mengisi tracer study.

\section{DAFTAR PUSTAKA}

[1] Alatas, H. (2013), Responsive Web Design dengan PHP dan Bootstrap, Yogyakarta : Lokomedia.

[2] Fowler, M. 2005. UML Distilled Edisi 3 Panduan Singkat Bahasa Pemodelan Objek Standar. Penerbit : Andi Yogyakarta.

[3] Jogiyanto. 2005. Analisis dan Desain. Penerbit : Andi Yogyakarta.

[4] Mulhim, Imam, Desain Web untuk Destop dan Mobile dengan Responsive Web Design, Maxikom. Palembang, 2014.

[5] Nailburg, E,. and Maksimchuk, R., 2001, UML for Database Design, USA: ADDISONWESLEY

[6] Pipim Boaduo, Nana Adu. 2009. Tracer Study As A Paradigm For The Enhancement of Quality Course Programmes Development in Higher Education Institutions in South Africa. www.docstoc.com/docs/20394050.

[7] Syafii, M. 2004. Membangun Aplikasi Berbasis PHP dan MySQL. Penerbit : Andi Yogyakarta.

[8] Siregar, 2010. Perancangan Portal Berbasis Web Dengan Menggunakan Php Dan MySQL Pada SMA Negeri 18 Medan, Sumatara utara.

[9] Vermeulen, L. 2006. The study of alumni: Professional success, commitment to the university, and the role of the academic learning environment. Netherlands : Lemma publisher.

[10] Welling, L., \& Thomson, L. (2003). PHP dan MYSQL Web Development. Sams Publishing. 